\title{
Cerebral tissue oxygen saturation values in volunteers and patients in the lateral decubitus and beach chair positions: a prospective observational study
}

\section{Valeurs de saturation en oxygène cérébral tissulaire de volontaires sains et de patients en décubitus latéral et en position assise: une étude observationnelle prospective}

\author{
Ingrid Meex, PhD · Joris Vundelinckx, MD - Klaas Buyse, MD • Francis Deburggraeve, MD • \\ Stephanie De Naeyer, MD · Veerle Desloovere, MD · Ludwig Anné, MD · Jan Truijen, MD • \\ Margot Vander Laenen, MD • René Heylen, MD, PhD • Cathy De Deyne, MD, PhD • \\ Frank Jans, MD, PhD
}

Received: 17 February 2015/Revised: 18 October 2015/Accepted: 27 January 2016/Published online: 4 February 2016 (C) Canadian Anesthesiologists' Society 2016

\begin{abstract}
Background The objective of this study was to describe changes in cerebral tissue oxygen saturation $\left(\mathrm{SctO}_{2}\right)$ due to changes in body position in healthy volunteers and in patients undergoing surgery under general anesthesia in the beach chair position $(B C P)$ and lateral decubitus position (LDP).

Methods In this prospective observational study, $\mathrm{SctO}_{2}$ was measured in 85 awake volunteers serially positioned every 15 min, beginning with the supine position $(S P)$ and followed by the beach chair, supine, and lateral decubitus positions. Cerebral tissue oxygen saturation was also measured supine and in either the BCP or the LDP in 195
\end{abstract}

This article is accompanied by an editorial. Please see Can J Anesth 2016; 63: this issue.

I. Meex, PhD $(\varangle) \cdot$ C. De Deyne, MD, PhD - F. Jans, MD, PhD Faculty of Medicine and Life Sciences, Hasselt University,

Hasselt, Belgium

e-mail: ingrid_meex@hotmail.com

I. Meex, PhD · J. Vundelinckx, MD - K. Buyse, MD .

F. Deburggraeve, MD · S. De Naeyer, MD · V. Desloovere, MD .

M. Vander Laenen, MD - R. Heylen, MD, PhD .

C. De Deyne, MD, PhD · F. Jans, MD, PhD

Department of Anesthesiology, Intensive care and Emergency

Medicine and Pain Therapy, Ziekenhuis Oost-Limburg, Schiepse

Bos 6, 3600 Genk, Belgium

L. Anné, MD · J. Truijen, MD

Department of Orthopedic Surgery, Ziekenhuis Oost-Limburg,

Schiepse Bos 6, 3600 Genk, Belgium patients (according to surgical preference) undergoing elective arthroscopic shoulder surgery. We measured the lowest stable $\mathrm{SctO}_{2}$ values in each position as well as changes in blood pressure and heart rate.

Results In healthy volunteers, the median (interquartile range [IQR]) lowest stable $\mathrm{Sct}_{2}$ value in the $\mathrm{SP}$ was 69 [66$71] \%$. A change in position to the BCP caused a small but statistically significant decrease in the median [IQR] lowest $\mathrm{SctO}_{2}$ value to 67 [65-70] \% ( $P=0.028$ compared with baseline). This decrease was associated with an increase in median [IQR] arterial pressure from 83 [78-88] $\mathrm{mmHg}$ in the SP to 85 [81-93] $\mathrm{mmHg}$ in the $B C P(P<0.001$ compared with baseline). In patients undergoing surgery in the $B C P$, the median [IQR] lowest stable $\mathrm{SctO}_{2}$ value was 55 [51-59] $\%$, which was significantly lower $(P<0.001)$ than the median [IQR] lowest $\mathrm{Sct}_{2}$ value in patients in the $\mathrm{LDP}(66$ [62-69] \%). More patients in the BCP group (57\%) showed $\mathrm{SctO}_{2}$ values $\leq 55 \%$ and/or a decrease of $\geq 20 \%$ from baseline (57\%) compared with the LDP group (5\% and 6\%, respectively; $P<0.001$ for each comparison).

Conclusions More than 55\% of patients undergoing arthroscopic shoulder surgery in the $B C P$ experience cerebral desaturation events. In volunteers without anesthesia, no desaturation events were observed. The clinical importance of these findings needs further investigation.

Résumé

Contexte L'objectif de cette étude était de décrire les changements de la saturation en oxygène cérébral tissulaire $\left(\mathrm{SctO}_{2}\right)$ provoqués par les changements de 
position du corps chez des volontaires sains et des patients subissant une chirurgie sous anesthésie générale en position assise (PAs - beach chair position) et en décubitus latéral (DL).

Méthode Dans cette étude observationnelle prospective, on a mesuré la $\mathrm{SctO}_{2}$ de 85 volontaires sains éveillés repositionnés en série toutes les 15 minutes, en commençant en position allongée (PAl) puis en position assise, puis allongée à nouveau, et finalement en décubitus latéral. La saturation en oxygène cérébral tissulaire a également été mesurée en position allongée et en PAs ou en DL chez 195 patients (selon la préférence chirurgicale) subissant une arthroscopie non urgente de l'épaule. Nous avons mesuré les valeurs stables de $\mathrm{SctO}_{2}$ les plus basses dans chaque position ainsi que les changements de tension artérielle et de fréquence cardiaque.

Résultats Chez les volontaires sains, la valeur stable moyenne (écart interquartile [ÉIQ]) la plus basse de $\mathrm{SctO}_{2}$ en PAl était 69 [66-71] \%. Un changement en PAs a provoqué une réduction, faible mais significative d'un point de vue statistique, de la valeur médiane [ÉIQ] la plus basse de $\mathrm{SctO}_{2}$ à $67 \quad$ [65-70] \% (P $=0,028$ comparativement aux valeurs de base). Cette réduction a été associée à une augmentation de la tension artérielle médiane [ÉIQ] de 83 [78-88] mmHg en PAl à 85 [81-93] mmHg en PAs $(P<0,001$ comparativement aux valeurs de base). Chez les patients subissant une chirurgie en PAs, la valeur médiane [ÉIQ] stable la plus basse de $\mathrm{SctO}_{2}$ était de 55 [51-59], soit significativement plus basse $(P<0,001)$ que la valeur médiane [ÉIQ] stable la plus basse telle que mesurée chez les patients en DL (66 [62-69] \%). La plupart des patients du groupe PAs (57\%) ont montré des valeurs de $\mathrm{SctO} 2 \leq 55 \%$ et/ou une réduction $\geq 20 \%$ par rapport aux valeurs de base (57\%) comparativement au groupe DL (5 \% et $6 \%$, respectivement; $P<0,001$ pour chaque comparaison).

Conclusion Plus de $55 \%$ des patients subissant une arthroscopie de l'épaule dans le groupe PAs ont subi des épisodes de désaturation cérébrale. Chez les volontaires sains n'ayant pas subi d'anesthésie, aucun épisode de désaturation n'a été observé. L'importance clinique de ces résultats nécessite des recherches plus approfondies.

Surgery in the beach chair position (BCP) has repeatedly been associated with significant hemodynamic changes that have the potential to compromise the cerebral circulation and place a patient at risk for cerebral ischemia. ${ }^{1,2}$ Moreover, for many surgical procedures (such as endoscopic shoulder surgery), optimal surgical visualization may require the use of controlled hypotension. Combining the BCP with controlled hypotension could increase the threat of inadequate cerebral perfusion. These assumptions are supported by case reports on adverse neurological sequelae after shoulder surgery in the BCP. $^{3,4}$

Cerebral oximetry near-infrared spectroscopy (NIRS) permits the detection of changes in cerebral tissue oxygen saturation $\left(\mathrm{SctO}_{2}\right)$. This technology has been extensively used to provide a noninvasive real-time indicator of cerebral hypoperfusion $^{5}$ - mainly during cardiac surgery. Not surprisingly, several groups have reported their experience on the use of cerebral oximetry during shoulder surgery in the BCP, and every group revealed significant decreases in $\mathrm{SctO}_{2}$ during the procedure. ${ }^{6-13}$ Nevertheless, many questions remain about what constitutes a "normal" $\mathrm{SctO}_{2}$ value and what $\mathrm{SctO}_{2}$ values are acceptable during general anesthesia.

The first objective of this study was to measure the changes in $\mathrm{SctO}_{2}$ values in healthy volunteers after positioning in the supine, $\mathrm{BCP}$, and lateral decubitus positions (LDP). Our second objective was to measure the changes in $\mathrm{SctO}_{2}$ values in patients after position changes during shoulder surgery under general anesthesia.

\section{Methods}

Cerebral tissue oxygen saturation monitoring

Bilateral $\mathrm{SctO}_{2}$ was measured using the FORE-SIGHT ${ }^{\mathrm{TM}}$ technology (CAS medical systems Inc, Branford, CT, USA) in both volunteers and patients. The FORE-SIGHT cerebral oximeter is a noninvasive device that uses four wavelengths of laser light to determine absolute cerebral oxygen saturation. Cerebral tissue oxygen saturation represents the oxygen saturation level in the microvasculature of brain tissue, which contains a mixture of arterial and venous blood (estimated to be 30/70\%). Sensors were applied to each frontotemporal area and covered to prevent external light interference. For each body position, the lowest stable (i.e., displayed for at least ten seconds) $\mathrm{SctO}_{2}$ value (right or left side) was recorded and used for statistical analysis. In the case of shoulder surgery, the attending anesthesiologist was blinded to the $\mathrm{SctO}_{2}$ data, and therefore, any changes in $\mathrm{SctO}_{2}$ could not have resulted in any changes in therapy such as blood pressure management.

\section{Volunteers}

The study protocol was approved by the local committee (Ziekenhuis Oost-Limburg, Genk, Belgium) for medical ethics, and written informed consent was obtained from all participants (patients and volunteers).

Volunteers were healthy (American Society of Anesthesiologists physical status I) males and females 18-30 yr of age. Monitoring of baseline bilateral $\mathrm{SctO}_{2}$ 
values was started in the supine position. The position was then changed to the beach chair, supine, and the lateral decubitus positions for $15 \mathrm{~min}$ each. Apart from the bilateral $\mathrm{SctO}_{2}$ monitoring, heart rate (HR), pulse oximetry, and noninvasive blood pressure measurements were taken every five minutes.

\section{Patients}

Patients scheduled to undergo elective arthroscopic shoulder surgery under general anesthesia in the BCP or LDP were enrolled in the study. Exclusion criteria were pre-existing cerebrovascular disease, peripheral vascular disease, and age $<$ $18 \mathrm{yr}$. Monitoring of baseline bilateral $\mathrm{SctO}_{2}$ values was started in the supine position and monitoring continued with the change to either the BCP or LDP. Allocation to either the BCP or the LDP group was determined by surgical preference.

\section{Anesthesia}

Anesthetic management was performed in both patient groups by the same team of anesthesiologists. Thirty minutes prior to surgery, all patients received an interscalene plexus block with a single injection of a maximum of $30 \mathrm{~mL}$ of $0.5 \%$ bupivacaine. All surgical procedures were performed under general anesthesia (propofol/rocuronium/remifentanil; $\mathrm{F}_{\mathrm{I}} \mathrm{O}_{2} 30 \%$ ). Standard monitoring (noninvasive blood pressure measurement on the contralateral arm, electrocardiography, peripheral oxygen saturation, and end-tidal capnography) was applied. The management of anesthesia and, when requested by the surgeon, controlled hypotension was left to the discretion of the attending anesthesiologist who was blinded to the cerebral oximetry values. In all patients, severe arterial hypotension [i.e., mean arterial pressure (MAP) $<60 \mathrm{mmHg}$ ] was countered by reducing the remifentanil or propofol infusions or by administering boluses of colloids, phenylephrine, or ephedrine.

\section{Statistical analysis}

Statistical analysis was performed using SPSS ${ }^{\circledR}$ V19.0 (SPSS Inc, Chicago, IL, USA). Discrete data were compared using the $\chi^{2}$ test. The normality of variable distributions was tested using the Kolmogorov-Smirnov test. Normally distributed continuous data were compared using the unpaired Student's $t$ test. Hemodynamic and cerebral oxygen saturation values were compared between groups using the Mann-Whitney U test. To compare values within the same group, the paired Wilcoxon test was used. Possible correlations between $\mathrm{SctO}_{2}$ and MAP were analyzed using the Pearson correlation test. The results are represented as median (interquartile range [IQR]), mean [standard deviation (SD)], or percent $(\%)$ as indicated. All reported $P$ values are two sided.

\section{Results}

Healthy volunteers

Ninety-one healthy volunteers with a mean (SD) age of 23 (3) yr were recruited from October 2008 to May 2010. Due to missing $\mathrm{SctO}_{2}$ data, six volunteers were excluded from further analysis. Characteristics of the 85 healthy volunteers are presented in Table 1.

In volunteers, changing the body position from supine to beach chair caused the median [IQR] lowest stable $\mathrm{SctO}_{2}$ value to decrease from $69 \%$ [66-71] to 67\% [65-70] $(P=$ 0.028 ). This decrease was associated with an increase in median MAP from 83 to $85 \mathrm{mmHg}(P<0.001$ compared with baseline), while HR and arterial oxygen saturation $\left(\mathrm{SpO}_{2}\right)$ remained stable. When the body position was changed again from beach chair to supine, the median [IQR] lowest stable $\mathrm{SctO}_{2}$ value was 68 [65-70] \% $(P=$ 0.47). Median [IQR] MAP decreased to 80 [74-87] $\mathrm{mmHg}$ $(P<0.001$ compared with the $\mathrm{BCP})$, while $\mathrm{HR}$ and $\mathrm{SpO}_{2}$ remained stable. When turned from supine to the right lateral decubitus position, the median [IQR] lowest stable $\mathrm{SctO}_{2}$ value remained at 68 [65-71] \%. Median [IQR] MAP further decreased to 75 [69-83] $\mathrm{mmHg}(P<$ 0.001 compared with supine). Detailed results obtained in the healthy volunteers are presented in Table 2 .

\section{Patients}

There were 236 patients recruited for the study; however, 41 of the participants were excluded from further analyses because $\mathrm{SctO}_{2}$ and/or hemodynamic data were incompletely recorded or stored. Of the 195 remaining patients, 101 and 94 patients underwent surgery in the $\mathrm{BCP}$ and LDP, respectively. The two patient groups were comparable regarding sex, American Society of Anesthesiologists status, pre-existing hypertension, and preoperative hemoglobin levels. The age of patients in the $\mathrm{BCP}$ was significantly higher than the age of patients in the LDP (Table 1).

Table 1 Characteristics

\begin{tabular}{llll}
\hline & Volunteers & Patients & P value \\
\hline Number, n & 85 & 195 & - \\
Age, yr (SD) & $23(3)$ & $53(13)$ & $<0.001$ \\
ASA status, n (I/II/III) & $85 / 0 / 0$ & $124 / 67 / 4$ & $<0.001$ \\
Hypertension, n (\%) & $0(0 \%)$ & $26(13 \%)$ & $<0.001$ \\
\hline
\end{tabular}

ASA = American Society of Anesthesiologists; SD = standard deviation 
Table 2 Results of healthy volunteers

\begin{tabular}{|c|c|c|c|c|}
\hline & SP & BCP & SP & LDP \\
\hline Lowest $\mathrm{SctO}_{2}(\%)$ & $69[66-71]$ & $67[65-70]$ & $68[65-70]$ & $69[65-71]$ \\
\hline HR (beats $\cdot \min ^{-1}$ ) & $68[61-76]$ & $68[63-76]$ & $67[61-75]$ & 68 [61-73] \\
\hline MAP (mmHg) & $83[78-88]$ & 85 [81-93] & 80 [74-87] & $75[69-83]$ \\
\hline $\mathrm{SpO}_{2}(\%)$ & 98 [97-99] & 98 [97-99] & 98 [97-99] & 98 [97-99] \\
\hline$\%$ decrease in $\mathrm{SctO}_{2}$ & $1[0-2]$ & $-1[-$ & & $0[-1-1]$ \\
\hline
\end{tabular}

Volunteers were serially moved from the supine position to the beach chair position, followed by a return to the supine position and a final change to the lateral decubitus position. Each position was held for $15 \mathrm{~min}$

Results are shown as median [interquartile range]. *Significant difference compared with previous position $(\mathrm{P}<0.05)$. BCP $=$ beach chair position; $\mathrm{HR}=$ heart rate; $\mathrm{LDP}=$ lateral decubitus position; $\mathrm{MAP}=$ mean arterial pressure; $\mathrm{SctO}_{2}=$ regional cerebral tissue oxygen saturation; $\mathrm{SpO}_{2}=$ peripheral capillary oxygen saturation; $\mathrm{SP}=$ supine position

In patients undergoing elective arthroscopic shoulder surgery, the median [IQR] lowest stable $\mathrm{SctO}_{2}$ value in the supine position before induction of anesthesia (during preoxygenation) was used as baseline (72 [70-75] \% and 73 [71-76] \% for the BCP and LDP groups, respectively; $P=$ $0.18)$.

In patients positioned in $\mathrm{BCP}$, the median [IQR] lowest stable $\mathrm{SctO}_{2}$ value during surgery was 55 [51-59] \%, which was significantly lower $(P<0.001)$ than the median [IQR] lowest stable $\mathrm{SctO}_{2}$ value in patients undergoing surgery in the LDP (66 [62-69] \%). In 57\% of the patients in the BCP group, a drop of $\geq 20 \%$ in $\mathrm{SctO}_{2}$ compared with baseline was observed, whereas this happened in only $6 \%$ of the patients in the LDP group. Detailed $\mathrm{SctO}_{2}$ data are presented in Table 3. The time course of the median $\mathrm{SctO}_{2}$ values during surgery in the BCP and LDP groups is shown in Figure.

After induction of anesthesia and change in position, MAP (measured at the level of the heart) decreased in each patient group, but this decrease was not significantly different between the two groups $(P=0.097)$. Nevertheless, assuming a decrease of $0.77 \mathrm{mmHg}$ for every centimetre gradient ${ }^{14}$ and an approximate gradient of $22 \mathrm{~cm}\left(30^{\circ}\right.$ angle) between the external auditory meatus and the site of the blood pressure cuff, the median [IQR] decrease in MAP measured at the level of the brain was significantly more important in the BCP group than in the LDP group (61 [57-68] $\mathrm{mmHg}$ vs 43 [31-46] $\mathrm{mmHg}$, respectively; $P<0.001)$.

For the patients in the BCP group, a correlation $\left(\mathrm{R}^{2}=\right.$ 0.4) was observed between the decrease in MAP (measured at the level of the brain) and the decrease in $\mathrm{SctO}_{2}$.

The median $[\mathrm{IQR}]$ end-tidal $\mathrm{CO}_{2}\left(\mathrm{EtCO}_{2}\right)$ at the moment of the lowest stable $\mathrm{SctO}_{2}$ value was 31 [29-34] $\mathrm{mmHg}$ in the BCP group and 31 [28-34] mmHg in the LDP group $(P=0.34)$.

\section{Discussion}

In this study, a very small decrease in $\mathrm{SctO}_{2}$ was observed in healthy volunteers when body position changed from the supine to the BCP. Only a very limited number of studies have been published on the impact of body positioning on $\mathrm{SctO}_{2}$ in healthy volunteers. ${ }^{15-18}$ Moreover, in these studies, the numbers of healthy volunteers studied were rather small (minimum, $n=5$; maximum, $n=28$ ) and different types of cerebral oximeters were used (NIRO $^{\mathrm{TM}},{ }^{15}$ Oxymon $^{\mathrm{TM}}{ }^{16}{ }^{\text {INVOS }}{ }^{\mathrm{TM}} \cdot{ }^{17,18}$ Generally, a decrease (although not significant in all studies) in $\mathrm{SctO}_{2}$ was reported when changing from the supine to the upright position, which is confirmed by the results from our current study.

In awake subjects, upright positioning activates the sympathetic nervous system, resulting in an increase in blood pressure. ${ }^{1}$ In our group of healthy volunteers, MAP increased from 83-85 $\mathrm{mmHg}$ when changing from the supine to the upright position (Table 2). This small increase in MAP was accompanied by a small decrease in $\mathrm{SctO}_{2}$.

In patients under general anesthesia, activation of the sympathetic nervous system to maintain cerebral perfusion in the sitting position is often blunted or absent. ${ }^{19}$ With $57 \%$ of our patients under general anesthesia revealing $\mathrm{SctO}_{2}$ values $<55 \%$ and a decrease of $\geq 20 \%$ from baseline in the $\mathrm{BCP}$, we confirm previous results on the frequent occurrence of cerebral tissue oxygen desaturation in patients undergoing arthroscopic shoulder surgery in the $\mathrm{BCP}^{6-11}$

The combination of general anesthesia and controlled hypotension resulted in a median decrease in blood pressure of $45 \mathrm{mmHg}$ in both of our patient groups. Brachial noninvasive blood pressure monitoring, as in our 
Table 3 Results of patients in beach chair and lateral decubitus position

\begin{tabular}{|c|c|c|c|c|}
\hline & SP & $\mathbf{B C P}$ & SP & LDP \\
\hline Lowest $\mathrm{SctO}_{2}(\%)$ & $72[70-75]$ & 55 [51-59] & $73[71-76]$ & 66 [62-69] \\
\hline HR (beats $\cdot \min ^{-1}$ ) & $79[71-92]$ & 59 [54-66] & $84[66-91]$ & 54 [49-64] \\
\hline MAP (mmHg) & $106[98-121]$ & 59 [51-66] & $110[98-122]$ & $63[57-74]$ \\
\hline cMAP (mmHg) & $106[98-121]$ & 42 [34-49] & $110[98-122]$ & $63[57-74]$ \\
\hline $\mathrm{SpO}_{2}(\%)$ & $99[98-100]$ & 97 [96-98] & 99 [98-99] & 98 [97-99] \\
\hline $\mathrm{SctO}_{2} \leq 60 \%, n(\%)$ & \multicolumn{2}{|c|}{$86(85)$} & \multicolumn{2}{|c|}{$16(17)$} \\
\hline $\mathrm{SctO}_{2} \leq 55 \%, n(\%)$ & \multicolumn{2}{|c|}{$57(56)$} & \multicolumn{2}{|c|}{$5(5)$} \\
\hline Time $\leq 55 \%(\min ) \dagger$ & \multicolumn{2}{|c|}{$16(15-73)$} & \multicolumn{2}{|c|}{$14(3-34)$} \\
\hline$\%$ decrease in $\mathrm{SctO}_{2}$ & \multicolumn{2}{|c|}{$21[15-28]^{*}$} & \multicolumn{2}{|c|}{$10[3-15]$} \\
\hline $\begin{array}{l}\geq 20 \% \text { decrease in } \\
\mathrm{SctO}_{2}, n(\%)\end{array}$ & \multicolumn{2}{|c|}{$57(56)$} & \multicolumn{2}{|c|}{$6(6)$} \\
\hline
\end{tabular}

Results are shown as median [interquartile range] unless otherwise indicated

$\dagger$ Mean (min-max)

* Significant difference compared with previous position $(\mathrm{P}<0.05)$

$\mathrm{BCP}=$ beach chair position; $\mathrm{cMAP}=$ estimated mean arterial pressure at the level of the brain; $\mathrm{LDP}=$ lateral decubitus position; $\mathrm{HR}=$ heart rate; $\mathrm{MAP}=$ mean arterial pressure; $\mathrm{SctO}_{2}=$ regional cerebral tissue oxygen saturation; $\mathrm{SpO}_{2}=$ peripheral capillary oxygen saturation; $\mathrm{SP}=$ supine position

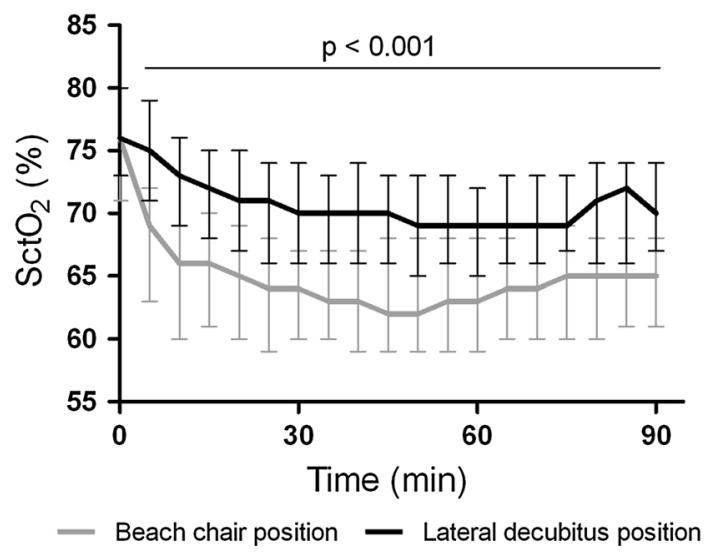

Figure Cerebral oxygen saturation $\left(\mathrm{SctO}_{2}\right)$ during arthroscopic shoulder surgery in the beach chair position (grey line) or lateral decubitus position (black line). Results are presented as median with interquartile range

study, overestimates the pressure in the elevated brain. ${ }^{13,14}$ When we apply the hydrostatic gradient ${ }^{14}$ to the blood pressure values of our patients, MAP would be approximately $42 \mathrm{mmHg}$ in the brain of patients in the BCP compared with $59 \mathrm{mmHg}$ measured at the level of the heart. The MAP at the top of the cortex could add another 6-9 mmHg to this gradient. ${ }^{20}$ This low cerebral MAP could help explain the lower $\mathrm{SctO}_{2}$ values in patients in the $\mathrm{BCP}$ compared with patients in the LDP. Nevertheless, the calculated $\mathrm{R}^{2}$ of 0.4 between a decrease in MAP and a decrease in $\mathrm{SctO}_{2}$ suggests that some patients with higher
MAPs may have lower $\mathrm{SctO}_{2}$ values and vice versa, so factors other than MAP must contribute to $\mathrm{SctO}_{2}$.

To maintain arterial pressure in patients undergoing shoulder surgery in the BCP, phenylephrine and/or ephedrine are most commonly used. Meng et al. observed that $\mathrm{SctO}_{2}$ did not change when ephedrine was used but decreased (together with cardiac output) after the use of phenylephrine. ${ }^{21}$ Ogoh et al. recently showed that vasoconstriction in the extracranial vasculature could be responsible for this decrease in $\mathrm{SctO}_{2}{ }^{22}$ To monitor the effect of vasopressor treatment on cerebral oxygenation, NIRS monitoring could be of further value.

In addition to the effects of the sitting position and hypotension in patients, ventilator strategies, such as hyperventilation, can influence cerebral blood flow and thus cerebral oxygenation. Recently, Murphy et al. observed a lower incidence of desaturation events and higher cerebral oxygenation values in a patient group with an $\mathrm{EtCO}_{2}$ of $40-42 \mathrm{mmHg}$ compared with a group with an $\mathrm{EtCO}_{2}$ of 30-32 mmHg. ${ }^{7}$ We report $\mathrm{EtCO}_{2}$ values of 31 $\mathrm{mmHg}$ in both of our patient groups, which corresponds with the standard practice group of Murphy et al. with lower $\mathrm{SctO}_{2}$ values.

Finally, NIRS technology measures saturation in the arterial, venous, and capillary compartments. Change in body position may alter the ratio of these compartments in the cerebral circulation, and therefore, reductions in $\mathrm{SctO}_{2}$ may not necessarily reflect an actual change in brain oxygenation. 
There are several limitations to the present investigation. Near-infrared spectroscopy measurements are limited to the prefrontal cortex; therefore, we were not able to measure oxygenation in other parts of the brain. Nearinfrared spectroscopy monitors are provided with an algorithm to remove the signal of extracerebral tissues from the actual value. Nevertheless, this could still contribute significantly to the signal. ${ }^{23}$ Patients were not randomized but allocated to either the $\mathrm{BCP}$ or the LDP according to surgical preference, and this preference may introduce bias. Finally, cerebral tissue oxygenation is a surrogate marker for clinically important outcomes such as adverse neurological events. We have not attempted to associate $\mathrm{SctO}_{2}$ values with clinically important outcomes. It is still unknown whether low $\mathrm{SctO}_{2}$ values presage worse postoperative neurological outcomes.

\section{Conclusion}

More than 55\% of the patients undergoing arthroscopic shoulder surgery in the $\mathrm{BCP}$ experienced cerebral desaturation events. In contrast, $\mathrm{SctO}_{2}$ in awake volunteers decreased only minimally. Further research should be performed to elucidate the clinical importance of cerebral desaturation events in patients undergoing shoulder surgery under general anesthesia in the beach chair position.

Author contributions: Joris Vundelinckx, Francis Deburggraeve, Stephanie De Naeyer, Veerle Desloovere, Ludwig Anné, Jan Truijen, Margot Vander Laenen, René Heylen, Cathy De Deyne, and Frank Jans were involved in the conception of the study. Joris Vundelinckx, Francis Deburggraeve, Stephanie De Naeyer, Veerle Desloovere, Margot Vander Laenen, René Heylen, Cathy De Deyne, and Frank Jans were involved in the design of the study. Joris Vundelinckx, Francis Deburggraeve, Klaas Buyse, Stephanie De Naeyer, Veerle Desloovere, Ludwig Anné, Jan Truijen,Cathy De Deyne, and Frank Jans were involved in data acquisition. Ingrid Meex and Veerle Desloovere were involved in the data analysis. Ingrid Meex, Joris Vundelinckx, Francis Deburggraeve, Klaas Buyse, Stephanie De Naeyer, Veerle Desloovere, Cathy De Deyne, and Frank Jans were involved in data interpretation. Ingrid Meex, Joris Vundelinckx, Francis Deburggraeve, and Frank Jans were involved in drafting the article. Ingrid Meex, Klaas Buyse, Stephanie De Naeyer, Veerle Desloovere, Ludwig Anné, Jan Truijen, Margot Vander Laenen, René Heylen, Cathy De Deyne, and Frank Jans were involved in revising the article.

Acknowledgement The authors sincerely thank the nursing and medical staff of the Department of Anesthesiology and the Department of Orthopedic Surgery.

Conflicts of interest None to declare.

Sources of support This manuscript is part of the Limburg Clinical Research Program (LCRP), UHasselt-ZOL-Jessa, supported by the
Limburg Sterk Merk foundation, Hasselt University, Ziekenhuis Oost-Limburg and Jessa Hospital.

\section{References}

1. Smith JJ, Porth CM, Erickson M. Hemodynamic response to the upright posture. J Clin Pharmacol 1994; 34: 375-86.

2. Alperin N, Lee SH, Sivaramakrishnan A, Hushek SG. Quantifying the effect of posture on intracranial physiology in humans by MRI flow studies. J Magn Reson Imaging 2005; 22: 591-6.

3. Pohl A, Cullen DJ. Cerebral ischemia during shoulder surgery in the upright position: a case series. J Clin Anesth 2005; 17: 463-9.

4. Bhatti MT, Enneking FK. Visual loss and ophthalmoplegia after shoulder surgery. Anesth Analg 2003; 96: 899-902.

5. Casati A, Spreafico E, Putzu M, Fanelli G. New technology for noninvasive brain monitoring: continuous cerebral oximetry. Minerva Anestesiol 2006; 72: 605-25.

6. Murphy GS, Szokol JW, Marymont JH, et al. Cerebral oxygen desaturation events assessed by near-infrared spectroscopy during shoulder arthroscopy in the beach chair and lateral decubitus positions. Anesth Analg 2010; 111: 496-505.

7. Murphy GS, Szokol JW, Avram MJ, et al. Effect of ventilation on cerebral oxygenation in patients undergoing surgery in the beach chair position: a randomized controlled trial. Br J Anaesth 2014; 113: 618-27.

8. Moerman AT, De Hert SG, Jacobs TF, De Wilde LF, Wouters PF. Cerebral oxygen desaturation during beach chair position. Eur $\mathrm{J}$ Anaesthesiol 2012; 29: 82-7.

9. Salazar D, Sears BW, Andre J, Tonino P, Marra G. Cerebral desaturation during shoulder arthroscopy: a prospective observational study. Clin Orthop Relat Res 2013; 471: 4027-34.

10. Salazar D, Sears BW, Aghdasi B, Francois A, Tonino P, Marra $G$. Cerebral desaturation events during shoulder arthroscopy in the beach chair position: patient risk factors and neurocognitive effects. J Shoulder Elbow Surg 2013; 22: 1228-35.

11. Koh JL, Levin SD, Chehab EL, Murphy GS. Neer Award 2012: cerebral oxygenation in the beach chair position: a prospective study on the effect of general anesthesia compared with regional anesthesia and sedation. J Shoulder Elbow Surg 2013; 22: 132531.

12. Closhen D, Berres M, Werner C, Engelhard K, Schramm P. Influence of beach chair position on cerebral oxygen saturation: a comparison of INVOS and FORE-SIGHT cerebral oximeter. J Neurosurg Anesthesiol 2013; 25: 414-9.

13. Ko SH, Cho YW, Park SH, Jeong JG, Shin SM, Kang G. Cerebral oxygenation monitoring of patients during arthroscopic shoulder surgery in the sitting position. Korean J Anesth 2012; 63: 297301.

14. Sia $S$. Hypotensive technique and sitting position in shoulder surgery. Anesth Analg 2003; 97: 1198-9.

15. Kurihara K, Kikukawa A, Kobayashi A. Cerebral oxygenation monitor during head-up and -down tilt using near-infrared spatially resolved spectroscopy. Clin Physiol Funct Imaging 2003; 23: 177-81.

16. Mehagnoul-Schipper DJ, Vloet LC, Colier WN, Hoefnagels WH, Jansen $R W$. Cerebral oxygenation declines in healthy elderly subjects in response to assuming the upright position. Stroke 2000; 31: 1615-20.

17. Fuchs $G$, Schwarz G, Kulier A, Litscher G. The influence of positioning on spectroscopic measurements of brain oxygenation. J Neurosurg Anesthesiol 2000; 12: 75-80.

18. Pollard V, Prough DS, DeMelo AE, Deyo DJ, Uchida T, Stoddart $H F$. Validation in volunteers of a near-infrared spectroscope for 
monitoring brain oxygenation in vivo. Anesth Analg 1996; 82: 269-77.

19. Porter JM, Pidgeon C, Cunningham AJ. The sitting position in neurosurgery: a critical appraisal. Br J Anaesth 1999; 82: 117-28.

20. Cullen DJ, Kirby RR. Beach chair position may decrease cerebral perfusion - catastrophic outcomes have occured. APSF Newsletter 2007; 22: 27.

21. Meng L, Cannesson $M$, Alexander BS, et al. Effect of phenylephrine and ephedrine bolus treatment on cerebral oxygenation in anaesthetized patients. Br J Anaesth 2011; 107: 209-17.
22. Ogoh S, Sato K, Okazaki $K$, et al. A decrease in spatially resolved near-infrared spectroscopy-determined frontal lobe tissue oxygenation by phenylephrine reflects reduced skin blood flow. Anesth Analg 2014; 118: 829-9.

23. Davie SN, Grocott HP. Impact of extracranial contamination on regional cerebral oxygen saturation: a comparison of three cerebral oximetry technologies. Anesthesiology 2012; 116: 83440. 